LSP International Journal, Vol. 5, Issue 2, 2018, 49-57

(C) Universiti Teknologi Malaysia

E-ISSN 2601-002X

DOI: https://doi.org/10.11113/lspi.v5n2.80

\title{
Learning to Teach: Patterns of Reflective Practice in Written Journal
}

\author{
Yee Bee Choo \\ Language Department, Institute of Teacher Education Tun Hussein Onn Campus, \\ Johor, Malaysia \\ Tina Abdullah \& Abdullah Mohd Nawi \\ Language Academy, Universiti Teknologi Malaysia, 81310 UTM Johor Bahru, Johor, Malaysia
}

Submitted: 18/11/2018. Revised edition: 9/12/2018. Accepted: 10/12/2018. Published online: 18/12/2018

\begin{abstract}
Reflective practice is essential for teacher education and pre-service teachers (PSTs) often reflect on their learning and teaching experiences to develop themselves into effective teachers in school later. In a case study of a PST in an institute of teacher education in Malaysia, this paper presents the levels of reflection practiced by the PST in his written journals after his digital storytelling presentation in a micro-teaching session. A six-level framework for reflective practice was derived from the written journal. The findings showed that the PST tended to reflect descriptively on the surface level rather than at the deepest level. It is recommended to provide more real teaching contexts for PSTs during teacher education in order to connect theoretical learning to practice.
\end{abstract}

Keywords: Reflective practice, journals, teacher education, micro-teaching

\section{INTRODUCTION}

Reflective practice was initiated by John Dewey (1933) and developed by Donald Schon (1983) who defined it as the practice by which professionals become aware of their implicit knowledge based and learned from their experiences. During teacher education, it is essential for the PSTs to reflect on their experiences in order to promote their professional development and improve the quality of teaching and learning (Matthew, Mathew, \& Peechattu, 2017). The PSTs need to reflect by applying the knowledge of content and pedagogy in their learning and teaching experiences. This practice informs them about their strengths and weaknesses in a lesson and helps them to find ways to overcome their problems.

*Correspondence to: Tina Abdullah (email: tinaabdullah@utm.my) 
During their studies in the teacher education program, the PSTs learnt not only the subjects they will teach for primary schools but also the pedagogy for teaching and learning strategies and methods. The theory and knowledge the PSTs gained about pedagogy for learning to teach can and should inform practice. However, this learning pedagogy sometimes place too much emphasis on practicing routines and discrete skills and not enough on decision-making and the development of judgment (Dewey, 1964). Thus, it is a challenge for PSTs to bring together theory and practice.

Besides, another challenge is the lack of experience by the PSTs in the real contexts. Sometimes, they "fail to remember, understand or apply ideas that have no connections to their experience and no contexts for acquiring meaning" (Hammerness et al., 2005, p.369). According to Guyton and Byrd (2000), extensive experience with real-life students in the classroom is a critical element in facilitating PSTs' reflective practice on teaching. Therefore, the PSTs might not be able to reflect on their practices with theoretical learning as they have very little exposure and experience in teaching.

There are multiple opportunities and various tools to support reflective practice such as typical classroom interactions, individual journaling and writing, as well as electronic modes of dialogue (Bean \& Stevens, 2002). Writing in a personal reflective journal is valuable to the PSTs to develop their metacognitive abilities and promote self-orientation and responsibility for the processes of their personal and collaborative learning (Bashan \& Holsblat, 2017). Above all, reflective journals help make connections between theory and practice that could improve one's learning experiences (Dyment \& O’Connell, 2011; Yee, Tina Abdullah \& Abdullah Mohd Nawi, 2016).

This study is based on a framework adapted from Gibb's (1988) model of reflective practice and Bloom's (2001) revised taxonomy of learning and teaching. The following table shows the comparison between these two levels and their convergence into an adapted framework.

Table 1 Adapted Framework of Reflective Practice based on Gibb (1988) and Bloom (2001)

\begin{tabular}{lll}
\hline Gibb's model of reflective practice & $\begin{array}{l}\text { Bloom's revised taxonomy of learning } \\
\text { and teaching }\end{array}$ & $\begin{array}{l}\text { Adapted framework of reflective } \\
\text { practice }\end{array}$ \\
\hline Description & Remember & Describing \\
Feeling & Understand & Feeling \\
Evaluation & Apply & Associating \\
Analysis & Analyse & Analysing \\
Conclusion & Evaluate & Assessing \\
Action Plan & Create & Creating \\
\hline
\end{tabular}

The two models are similar in some levels like "Evaluation-Evaluate" and "AnalysisAnalyse" but the main difference is that Gibb's model is cyclical in nature while Bloom's taxonomy is a pyramid that begins with the most frequent occurring and lowest level of learning and teaching which is "Remember" to the least and highest level of "Create". Though they are different in the structure of the levels of learning, they both begin with the most descriptive form at surface level of learning and progress to deeper levels of learning. Reflective practice is a form of critical thinking that involves the use of cognitive and metacognitive strategies to analyse and process information while 
personal feelings reside (Too, 2013). It allows one to step back from his learning and teaching experiences to develop his thinking skills and improve on future performance by analysing his experience.

Therefore, this framework has been developed in line with the six-level model based on Gibb's (1988) model of reflective practice and Bloom's (2001) revised taxonomy of learning and teaching (as shown in Figure 1): (1) Describing (description of events on the PSTs' learning and teaching experiences); (2) Feeling (their feelings, thoughts, perceptions and attitudes of the learning and teaching experiences); (3) Associating (relating the experiences to past experiences, assumptions and values by linking the theory and practice with various sources from literature review or getting feedback from the peers); (4) Analysing (analysing their strengths and weaknesses while connecting their causes and consequences in the learning and teaching experiences); (5) Assessing (justifying and critiquing their actions on the values and purposes of their learning and teaching experiences); and (6) Creating (planning and producing for their present and future classroom practices, as well as creating awareness on their roles as teachers in the future). Figure 1 clearly illustrates the model:

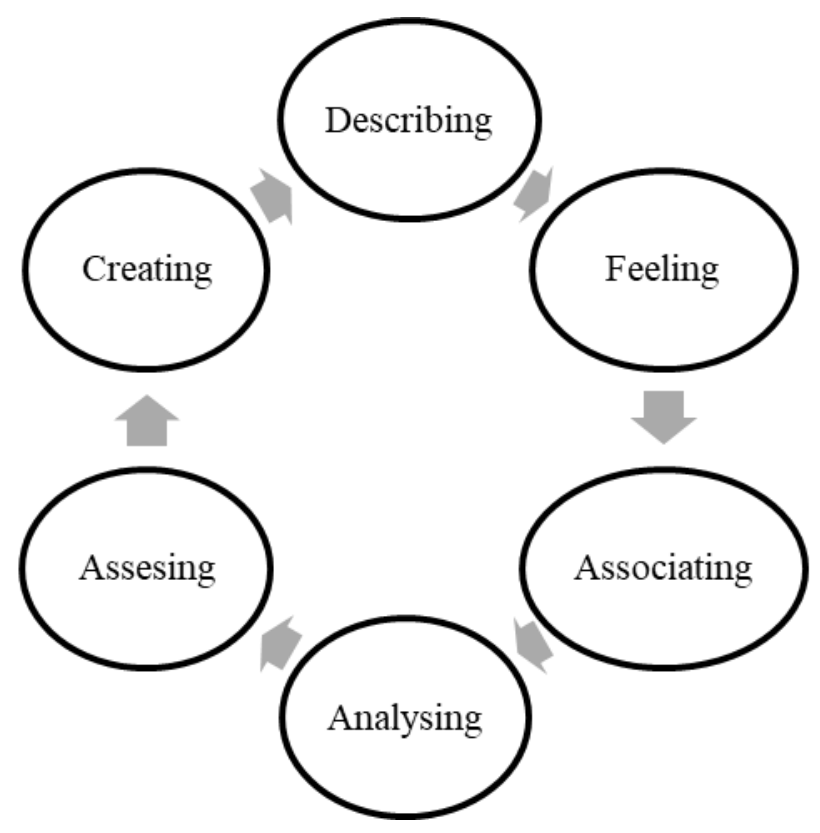

Figure 1 Adapted framework for reflective practice from Gibb's (1988) model of reflective practice and Bloom's (2001) revised taxonomy of learning and teaching

\section{RESEARCH QUESTIONS}

This study presents the patterns of reflective practice engaged by a PST in his written journal after his digital storytelling presentation during a micro-teaching session. The patterns are examined according to the adapted framework developed for this study. Specifically, the research question is: 
"What are the common levels of reflective practice in the journal written by the PST?"

\section{METHODOLOGY}

This study adopted the methodology of a case study. According to Yin (2009), by using the case study, a researcher is able to investigate a phenomenon "in depth and within real-life contexts, especially when boundaries between the phenomenon and its contexts are not clearly evident" (p.18). The study was conducted on a PST who presented his digital storytelling in the teaching of children's literature. The instrument used was the reflective journal written by the participant. Reflective journal is a means of collecting data in qualitative research (Janesick, 1999), and it can make one's experiences, opinions, thoughts, and feelings visible and becomes an acknowledged part of the research design, data generation, analysis, and interpretation process (Ortlipp, 2008). The PST's reflective journal provided rich qualitative evidence of the levels of reflective practice he used during his learning experiences.

As this participant had not gone for any teaching practice, the context in this study is during a micro-teaching session when he taught children's literature in front of his peers and lecturer.

\section{FINDINGS AND DISCUSSION}

This study employed content analysis to analyse and interpret the data from the reflective journal. The authors interpreted the data collaboratively, following a process of iterative readings of the data. A six-level framework for reflective practice (Figure 1) was derived from the selected journal. For the purpose of this paper, the discussion is presented based on common levels of reflective practice engaged by the participant. Appendix 1 shows a sample of the reflective journal written by the participant and the level of reflective practice for each sentence. This entry comprised six paragraphs, 31 sentences and 654 words. A sentence-by-sentence analysis was carried out for the journal entry as shown in Appendix 1. The result of the levels of reflective practice is tabulated in Table 2.

Table 2 The Result of the Levels of Reflective Practice

\begin{tabular}{llllllll}
\hline $\begin{array}{l}\text { Level of } \\
\text { Reflective }\end{array}$ & Describing & Feeling & Associating & Analysing & Assessing & Creating & Total \\
Practice & & & & & & \\
\hline $\begin{array}{l}\text { Frequency } \\
\text { Percentage }\end{array}$ & 8 & 6 & 19 & 16 & 16 & 4 & 31 \\
$(\%)$ & & & & & 13 & 10 & 100 \\
\hline
\end{tabular}


According to Table 2, the participant engaged the most at the first and second levels of reflective practice, Describing at $26 \%$ and Feeling at 19\%, followed by Associating and Analysing ( 16\%) and Assessing at 13\%. However, the participant seldom reflected at the highest level of Creating as it was only $10 \%$ from his journal entry. This shows that the participant tended to reflect descriptively on the surface level rather than at the deepest level.

The most common level of reflective practice, Describing, was manifested when the participant described and narrated the coursework which he did for creating digital story and presenting the digital storytelling. He narrated his learning experiences on the task of creating and delivering digital storytelling. He described the process of doing the tasks. He also identified his strengths and weakness through digital storytelling. His strengths were diction, voice projection and body movement but his weakness was time management.

At the second level, Feeling, he felt he should thank God and the lecturer for assisting him in completing the coursework. He thought that he did not use the time given in the best way during the digital storytelling and he wished he would learn from the mistakes and improve himself later. He also felt that he should use digital storytelling in the classroom as it was enjoyable.

The third level is Associating, which enables the participant to make the connection of the complex process of creating digital story. He was also able to associate the experiences with his assumptions and values as he could relate the didactical concepts to align with the pedagogical approach, teachers needed a manageable number of points of orientation to align it with the personality of a learner and cognition.

The next level, Analysis, indicates a higher level of reflective practice which verifies information to help the PST to analyse his strengths and weaknesses. The PST was able to reason the use of digital story in the classroom. He could analyse his weaknesses in digital storytelling as he did not make a longer digital story and he was lack of preparation before the delivery of digital storytelling.

The fifth level, Assessing, helps the PST to justify his learning experiences with actions. The PST could evaluate "the next step involves making methodological changes and consulting psycholinguistic insights to bring the principles closer to the process of instruction and language learning on a day-to-day basis". He also learnt he should read more books to better equip himself and improve himself. From there, he was able to derive and expand didactical concepts, giving a manageable number of points of orientation.

The highest level of reflective practice is Creating, a level that creates awareness in the PST as he was aware about how to make the literature lesson interesting for his pupils and suit the level of pupils with the pedagogical approach. This level was found as the least common level of reflective practice employed when compared to other levels. However, this level prepares the PST for his future role as a teacher and it is essential for teacher education to make PSTs become aware of the learning and teaching experiences that inform them of their practice.

Although this study indicated a positive outcome in reflective practice, the highest level of reflective practice (Creating) was low compared to the lowest level (Describing). This was supported by Too's (2013) study that only $27 \%$ of his PSTs engaged at the highest level of reflective practice which was "Transformation". At this level, his participants "exhibited changes of perspective or adoption of a new approach towards issues as a result of their reflective practice" (Too, 2013, p.168). This highest level of reflective practice implies the transformation of perspectives as it requires the 
recognition and change in beliefs and values that are assimilated from our experiences and environment which are governed by our actions (Kember, McKay, Sinclair, \& Wong, 2008). The PST need a new perspective if he wants to transform his role from a pre-service teacher to a teacher in his career.

However, the lack of teaching experience may become a catalyst that hinders him from reflecting deeply. Bean and Stevens (2002) explained that lack of exposure and experience in teaching in real classroom situations have caused the PSTs to rely on generalised statements to summarise their thinking as they spend limited time or effort to contemplate on instructional issues at application level. Thus, this study demonstrates the need to provide PSTs with a context of a classroom to expose them to the real scenario in teaching and learning experiences as the microteaching is not sufficient to provide them with the practice that they need.

\section{CONCLUSION}

The findings show that the PST reflected most commonly in the lowest level of description but least common in the highest level of creation. The lack of reflecting at the highest level might be due to the lack of real teaching context. Yee, Tina Abdullah \& Abdullah Mohd Nawi (2016) supported that when the PSTs participate in the actual teaching and reflect on their experience, there is likely to be a connection between theory and practice.

Therefore, teacher education should emphasise more on opportunities to practice and reflect in the classroom rather than "book learning" (Hammerness et al., 2005). The PSTs should be given more opportunities to participate in the real classroom practice by undergoing practicum sessions in more than once throughout their preparation programmes. Another recommendation is to establish a school setting in the teacher training institute where the PSTs and educators can work together in actual classrooms. This is to enable the PSTs to connect theoretical learning to practice by interpreting their experiences and expanding their repertoire, so that they can become effective teachers in the future.

\section{REFERENCES}

Anderson, L. W., \& Krathwohl, D. R. 2001. A Taxonomy for Learning, Teaching and Assessing: A Revision of Bloom's Taxonomy of Educational Objectives. New York: Longman.

Bashan, B., \& Holsblat, R. 2017. Reflective Journals as a Research Tool: The Case of Student Teachers' Development of Teamwork. Cogent Education. 4: 1-15. https://doi.org/10.1080/2331186X.2017.1374234.

Bean, T. \& Stevens, L. 2002. Scaffolding Reflection for Preservice and Inservice Teachers. Reflective Practice. 3(2): 205-218.

Dewey, J. 1964. The Relation of Theory to Practice in Education. In Reginald D.A. (Eds.). John Dewey On Education. Chicago: University of Chicago Press. 
Dewey, J. 1933. How We Think: A Restatement of the Relationof Reflective Thinking to the Educative Process. Boston: Houghton-Mifflin.

Dyment, J. E., \& O'Connell, T. S. 2011. Assessing the Quality of Reflection in Student Journals: A Review of the Research. Teaching in Higher Education. 16: 81-97. doi:10.1080/1356 2517.2010.507308.

Gibbs, G. 1988. Learning by Doing: A Guide to Teaching and Learning Methods. Further Education Unit. Oxford Polytechnic: Oxford.

Guyton, E., \& Byrd, D. (Eds.). 2000. Standards for Field Experiences in Teacher Education. Reston, VA: Association of Teacher Educators.

Hammerness, K., Darling-Hammond, L., Bransford, J., Berliner, D., Cochran-Smith, M., McDonald, M., \& Zeichner, K. 2005. How Teachers Learn and Develop. In L. Darling-Hammond and J. Bransford (Eds.). Preparing Teachers for a Changing World. San Francisco, CA: Jossey-Bass Educational Series. 358-388.

Janesick, V. J. 1999. A Journal About Journal Writing as a Qualitative Research Technique: History, Issues, and Reflections. Qualitative Inquiry. 5: 505-524. doi:10.1177/107780049900500404.

Kember, D., McKay, J., Sinclair, K., \& Wong, F. K. Y. 2008. A Four-Category Scheme for Coding and Assessing the Level of Reflection in Written Work. Assessment \& Evaluation in Higher Education. 33(4): 363-379.

Mathew, P., Mathew, P., \& Peechattu, P. J. 2017. Reflective Practices: A Means to Teacher Development. Asia Pacific Journal of Contemporary Education and Communication Technology (APJECT). 3(1): 126-131. Retrieved from www.apiar.org.au.

Ortlipp, M. 2008. Keeping and Using Reflective Journals in the Qualitative Research Process. The Qualitative Report. 13(4): 695-705. Retrieved from http://nsuworks.nova.edu/tqr/voll3/iss4/8.

Schon, D. 1983. The Reflective Practitioner: How Professionals Think in Action. New York: Basic Books.

Too, W. K. 2013. Facilitating the Development of Pre-service Teachers as Reflective Learners: A Malaysian Experience. The Language Learning Journal. 41(2): 161-174.

Yee, B. C., Tina Abdullah, \& Abdullah Mohd Nawi. 2016. Supporting and Improving Reflective Practice among Pre-Service Teachers through WhatsAPP. Jurnal Pendidikan Nusantara. Special Edition April 2016: 53-72.

Yin, R. K. 2009. Case Study Research: Design and Methods. 4th Ed. Thousand Oaks, CA: Sage. 
Appendix 1

\section{Reflective Journal Entry}

Level of Reflective

Practice

First of all I would like to thank god, for giving me the strength and ability to finish this Stories for Young Learner, LGA coursework. I would also like to thank the lecturer for giving me clear instructions and are always available in case if $I$ need to seek guidance regarding to the coursework.

First of all, this assignment consists of 2 tasks. For the first task, we were required to find and select suitable story from the textbook and create a digital story. Digital story is an element that makes $21^{\text {st }}$ century learning. Digital Storytelling has been popular in various educational contexts as a powerful tool for cognitive and literacy development in the digital age. The creation of a digital story is a complex process in which the creator utilizes different skills and literacies in order to produce a meaningful multimedia text. Learning occurs at different levels and dimensions when the digital story creator draws upon social cultural knowledge, relates life experience, and interacts with peers and instructors to work through this multi-staged project. Thus, creating a digital story is also a process of negotiation. While deciding on the theme, the images, the language and other elements of the digital story, the creator needs to negotiate internal conflicts, relations with the social world and the different modes used to tell the story. From this task, I have been taught the way to use Windows Movie Maker in order to create my own digital story.

Next, my weakness from the peer evaluation form is my time management. From this task, I realised that I did not use the time given in the best way. I did not manage to make longer digital story and the timing to tell my stories was also not arranged properly. So, I learned that I need to use the time given properly in order to attract pupils' attention and centalising their focus on my digital storytelling.

Next, we were required to deliver a story along with the digital storytelling. At first, this task is quite of a challenge because I am not used to tell stories in front. My strength that I discovered in this task is that my diction, voice projection and body movement is my strength. However, one of my weaknesses that I have discovered in this task is, I am inadequately prepared in terms of pedagogical knowledge to tell stories to kids and approaches that needed to be used. Along the process, I learned and read books regarding pedagogical knowledge for stories for young learners, to better equip myself. I have learnt from my mistake and hope I will be able to

Feeling

Feeling

Describing

Describing

Describing

Analysing

Associating

Associating

Describing

Associating

Assessing

Describing

Feeling

Analysing

Assessing

Describing

Analysing

Describing

Analysing

Assessing

Feeling 
improve for the next course. From the completion of this coursework I Creating become aware that how, with a little initiative, teachers can adapt children's stories to be more and interesting and to better suit their teaching goals. Stories can be used as a valuable teaching and learning tool. Using digital stories can help learners improve their listening skills and their pronunciation, Describing Analysing they can also be useful for teaching vocabulary and sentence structures. Probably the greatest benefit to use digital stories in the classroom is that they are enjoyable.

And after completing this coursework I am aware of the level of our Creating pupils should be suited and aligned with the pedagogical approach. Pedagogical principles should be aligned with the personality of a learner and Associating cognition. From there, one derives and expands didactical concepts, giving Associating teachers a manageable number of points of orientation. The next step Creating involves making methodological changes and consulting psycholinguistic insights to bring the principles closer to the process of instruction and language learning on a day-to-day basis.

From this coursework I have learned a lot and I am keen to improve Assessing myself. Finally I would like to thank the lecturer once again and everybody Feeling who is directly or indirectly involved in the completion of this coursework. 